\title{
Ordering of Warships for the Brazilian Navy Using the New Method: AHP- Gaussian with Pearson's Correlation
}

\author{
Carlos Francisco Simões GOMES ${ }^{\text {a,1, }}$, Marcus Vinícius Gonçalves RODRIGUES a, Igor \\ Pinheiro de Araújo COSTA ${ }^{\mathrm{a}}$ and Marcos dos SANTOS ${ }^{\mathrm{b}}$ \\ ${ }^{a}$ Federal Fluminense University - UFF, Niterói, RJ, Brazil \\ ${ }^{\mathrm{b}}$ Military Engineering Institute - IME, Rio de Janeiro, RJ, Brazil.
}

\begin{abstract}
This paper aims to support the selection decision of a medium-sized warship (between 2,000 and 3,000 tons), to be built in Brazil, presenting the alternatives in a hierarchical manner. Among the various multicriteria decision analysis (MCDA) methods, we used the analytic hierarchy process (AHP) as a basis. Throughout the study, we will propose some adjustments to the AHP in order to make the decision more robust (such as the use of the Gaussian factor and Pearson's correlation). The criteria were listed and their respective weights were assigned in light of the National Defense Strategy, the Navy's Strategic Program and interviews carried out with Brazilian navy officers with more than twenty years of career. To list the criteria, we adopted the critical incident technique. The use of the adapted AHP method in choosing the unit to be built can be considered as a transparent way, with a clearly scientific bias, for the Brazilian society to have the perception that the best option was made among the three models of warships presented.
\end{abstract}

Keywords. Multicriteria Decision Analysis; Analytic Hierarchy Process (AHP); Warship; Brazil's navy.

\section{Introduction}

According to the Brazilian national defense strategy [1], the science, technology and innovation policy for national defense aims to stimulate innovation, scientific and technological development of interest to the country's strategy. This happens through a national planning for the development of products with high technological content; with coordinated involvement of civil and military scientific and technological institutions, industry and universities; with the definition of priority areas and their respective technologies of interest; and the creation of instruments to encourage research into materials, equipment and systems for defense or dual employment. It is worth noting that all these actions seek to enable a technological and operational vanguard based on strategic mobility, flexibility and the ability to deter or surprise. Within this scope, despite other political and/or financial difficulties, the Brazilian navy (BN) has been trying to develop its own naval resources with its own technology.

${ }^{1}$ Corresponding Author, Carlos Francisco Simões GOMES, Federal Fluminense University - UFF, Niterói, RJ, Brazil; E-mail: cfsg1@bol.com.br 
Brazil has a modern armed force equipped and prepared to guarantee its sovereignty and strategic interests, supporting its foreign policy and positions in international forums, even in peace times. The $\mathrm{BN}$ is supposed to have 18 warships (including frigates, corvettes and destroyers) in order to permit the arrangement of two task groups (one with close escort to a main body and another for the away defense of the surface action group). Escort ships must have anti-submarine, anti-surface and anti-air point defense capabilities (missile availability). They must have the capacity to transport, supply, operate and maintain helicopters, capable of attacking surface and submarine targets, in addition to carrying out clarification operations.

Since the last decade of the 20th century, the budget made available by the Brazilian Federal Government has fallen short of the amount needed to meet the needs of the BN, making it almost impossible to allocate the necessary and sufficient credits for operation, maintenance, and re-equipment. The armed forces, especially the $\mathrm{BN}$, have suffered budgetary restrictions that is resulting in not meeting the minimum needs of the naval force, also resulting in operational capacity reduction and in the accumulation of demands. According to Almeida et al. [2], Moreira et al. [3] and Tenorio et al. [4], due to progressive budget restrictions, nowadays, the $\mathrm{BN}$ has an undersized fleet of only 11 escort ships (many of which are close to the conclusion of their useful live), resulting in non-compliance with the minimum necessities of the naval force, diminishing the operational capacity and with the accumulation of requests from different sources.

Gomes et al. [5], Oliveira et al. [6] and Rodrigues et al. [7], highlight in their work that, in general, selection problems must be modeled by multicriteria methods. In this context, this work aims to select a new warship to be built by the BN through the application of the Analytic Hierarchy Process (AHP), which is one of the most classic multiple criteria decision support method (from the American school). The AHP was chosen because it is a compensatory and hierarchical method mainly indicated for problems with an average number of alternatives and criteria, considering the discrimination of results and cognitive effort in paired comparisons. According to Costa et al. [8], Jardim et al. [9] and Moreira et al. [10], the concepts of hierarchy and compensatory decision rules are in accordance with the military culture, which facilitates the analysis by specialists. We also proposed a new approach to the AHP method in order to make the decision more robust (such as the use of the Gaussian factor and Pearson's correlation).

\section{Literature Review}

AHP, developed by Saaty [11], is one of the most classic methods of the American school (non-compensatory methods) to quantitatively treat complex problems with multiple decision criteria. The essence of the method lies in the weighting of the criteria weights, by comparing two by two, using a metric known as: Saaty's fundamental scale, which can be found in Table 1 .

Table 1. Saaty's Fundamental Scale

\begin{tabular}{ccc}
\hline Reference & Meaning & Explanation \\
\hline 1 & Equal importance & The two alternatives contribute equally to the goal. \\
3 & Moderate importance & $\begin{array}{c}\text { Experience and judgment slightly favor one activity over } \\
\text { another. }\end{array}$ \\
5 & Strong importance & $\begin{array}{c}\text { Experience and judgment strongly favor one activity over } \\
\text { another. }\end{array}$ \\
\hline
\end{tabular}




\begin{tabular}{ccc}
\hline 7 & Very strong importance & $\begin{array}{c}\text { One alternative is strongly favored over another. } \\
\text { The evidence is in favor of one alternative over another } \\
\text { (to the greatest extent possible) }\end{array}$ \\
$2,4,6,8$ & Intermediate values & $\begin{array}{c}\text { Used to express preferences that are between the } \\
\text { references above. }\end{array}$ \\
\hline
\end{tabular}

Source: Adapted from Saaty [4]

According to Saaty [11], in order to ensure that the decision has consistency, the AHP method calculates the Consistency Ratio (CR) between the Consistency Index (CI) of the judgments and the Random Consistency Index (RI). The maximum tolerance for inconsistency allowed by the model is ten percent, so $\mathrm{CR} \leq 0.1$. If $\mathrm{CR}>0.1$, the decision maker must make a new evaluation of the criteria. Below is a summary of the AHP method according to Santos et al. [12] and Souza et al. [13]:

a) Formation of the decision matrices $(\mathrm{m} x \mathrm{n})(1)$ :

$$
\left[\begin{array}{ccc}
a 11 & \cdots & a 1 n \\
\vdots & \ddots & \vdots \\
a m 1 & \cdots & a m n
\end{array}\right]
$$

The decision matrices express the number of times an alternative dominates or is dominated by the others.

b) Calculation of the eigenvector (Wi) (2):

$$
W i=\left(\prod_{j=1}^{n} W_{i j}\right)^{1 / n}
$$

This step consists in ordering the priorities or hierarchies of the studied characteristics.

c) Calculation of eigenvectors normalization, enabling comparability between criteria and alternatives (3):

$$
T=\left|\frac{W 1}{\sum W i} \quad ; \quad \frac{W 2}{\sum W i} \quad ; \quad \frac{W 3}{\sum W i} \quad ; \quad \frac{W n}{\sum W i}\right|
$$

d) Determination of the index that relates the criteria of the consistency matrix and the criteria weights (4):

$$
\lambda_{\max }=T \times W
$$

e) Determination of the consistency index (CI) (5):

$$
C I=\frac{\lambda_{\max }-n}{(n-1)}
$$

This step allows the decision maker to assess the degree of inconsistency of the paired judgments matrix.

f) Calculation of the consistency ratio (CR) (6):

$$
C R=\frac{C I}{R I}
$$


Where, RI is the random consistency index obtained for a reciprocal matrix of order $n$. This step allows evaluating the inconsistency due to the order of the judgment matrix. If the $\mathrm{CR}$ value is greater than 0.10 , the decision maker must review the model or judgments.

\section{Methodology}

The development of this research took place, in summary, through the steps below:

i.Identification and definition of the problem with the $\mathrm{BN}$;

ii.After defining the problem, we performed a literature review to contextualize the study and map the main methods used by the authors;

iii.Definition and analysis of the main technical characteristics of the three warships that could be built by the $\mathrm{BN}$;

iv.Definition of the mathematical modeling tool to be used (in this case, we choose the AHP);

v.Interview with ten $\mathrm{BN}$ officers (with more than twenty years of operational experience) in order to list the relevant criteria for choosing the most suitable warship for the Brazilian navy's needs, as well as establishing the inter-criteria weights;

vi.Structuring the problem in the mental map form based on the concept established by specialists who are knowledgeable about the warship process of operation and maintenance;

vii.Definition of the final criteria for choosing the warship;

viii.Modeling the problem in a spreadsheet;

ix.After ranking by AHP, we identified a possibility of improving the method (bringing more robustness to the choice of the first alternative). The improvement consisted in the correction of the weights modulus by using the Gaussian factor and the Pearson's correlation;

x.Ranking of alternatives and comparison of results with results obtained in traditional AHP.

\section{Data Analysis and Results}

The BN started in 1994 the construction of the Corvette Barroso and finished the construction in 2008. Corvette Barroso is a medium-sized 2,500-ton warship that was launched only 14 years after the start of work (thus, they had a new ship in their arsenal but not modern compared to other models available on the market).

Nowadays, with the need to build new warships to compose the fleet, the $\mathrm{BN}$ is facing a new challenge, which is: to replicate the model of the current Corvette Barroso, build a slightly modernized ship (2,600 ton corvette) or build a model with more significant upgrades (3,000 ton corvette). It is important to highlight that the decisionmaking process must meets the requirements of the $\mathrm{BN}$, also prioritizing cost reduction. We collected the three warships' data, with the main technical characteristics of the ships, from Vogt's [14] study.

After the interview with experts from the $\mathrm{BN}$, nine criteria were considered for choosing the warship to be built. They are listed below: 
$\left(\mathrm{C}_{1}\right)$ Action radius: greatest distance (in nautical miles) the ship can travel from its base and return without refueling;

$\left(\mathrm{C}_{2}\right)$ Fuel endurance: time interval (in days) that a ship can navigate without refueling with speed at 15 knots.

$\left(\mathrm{C}_{3}\right)$ Autonomy: maximum interval of time (in days) that a ship can operate without any type of supplies (fuel, drinking water, foodstuff, etc.).

$\left(\mathrm{C}_{4}\right)$ Primary cannon: a weapon with a high rate of fire that functions to warn or neutralize possible threats, such as ships, aircraft or missiles. It is called "primary" when the ship has other alternative guns, usually of smaller caliber.

$\left(\mathrm{C}_{5}\right)$ Secondary cannon: an alternative cannon to the "primary cannon", usually of smaller caliber.

$\left(\mathrm{C}_{6}\right)$ AAW missiles: anti-aircraft warfare missiles.

$\left(\mathrm{C}_{7}\right)$ Initial Cost: cost of obtaining or building a ship.

$\left(\mathrm{C}_{8}\right)$ Life Cycle Cost: life cycle cost of a ship, includes the purchase (or construction), operation and modernization. The purchase price represents about $25 \%$, the expenses for crew and operations account for $67 \%$, and the possible modernization corresponds to $8 \%$.

$\left(\mathrm{C}_{9}\right)$ Construction Time: this criterion is self-explanatory, considering from the start of the project to the actual delivery of the ship to the operating sector.

At first, we applied the traditional AHP method to our problem. Table 2 illustrates the problem decision matrix and its normalization.

Table 2. Decision Matrix and its normalization

\begin{tabular}{|c|c|c|c|c|}
\hline Type & Reference & (1) & (2) & (3) \\
\hline \multirow{9}{*}{$\begin{array}{c}\text { Decision } \\
\text { Matrix }\end{array}$} & $\mathrm{C} 1$ & 4000 & 9330 & 10660 \\
\hline & $\mathrm{C} 2$ & 11 & 26 & 30 \\
\hline & C3 & 30 & 25 & 35 \\
\hline & $\mathrm{C} 4$ & 25 & 25 & 120 \\
\hline & $\mathrm{C} 5$ & 1 & 2 & 2 \\
\hline & C6 & 0 & 1 & 1 \\
\hline & $\mathrm{C} 7$ & $\mathrm{R} \$ 290,000,000$ & $\mathrm{R} \$ 310,000,000$ & $\mathrm{R} \$ 310,000,000$ \\
\hline & $\mathrm{C} 8$ & $\mathrm{R} \$ 592,000,000$ & $\mathrm{R} \$ 633,000,000$ & $\mathrm{R} \$ 633,000,000$ \\
\hline & C9 & 6 years & 8 years & 8 years \\
\hline \multirow{9}{*}{$\begin{array}{c}\text { Normalized } \\
\text { Decision } \\
\text { Matrix }\end{array}$} & $\mathrm{C} 1$ & 0.1667 & 0.3889 & 0.4443 \\
\hline & $\mathrm{C} 2$ & 0.1641 & 0.388 & 0.4477 \\
\hline & $\mathrm{C} 3$ & 0.3333 & 0.2777 & 0.3888 \\
\hline & $\mathrm{C} 4$ & 0.147 & 0.147 & 0.7058 \\
\hline & $\mathrm{C} 5$ & 0.2 & 0.4 & 0.4 \\
\hline & C6 & 0 & 0.5 & 0.5 \\
\hline & C7 & 0.3483 & 0.3258 & 0.3258 \\
\hline & $\mathrm{C} 8$ & 0.3483 & 0.3258 & 0.3258 \\
\hline & C9 & 0.4 & 0.3 & 0.3 \\
\hline
\end{tabular}

Source: Done by the authors.

Table 3 illustrates the weight matrix and its normalization.

Table 3. Weight Matrix and its Normalization

\begin{tabular}{ccccccccccc}
\hline Type & Reference & $\mathbf{C}_{\mathbf{1}}$ & $\mathbf{C}_{\mathbf{2}}$ & $\mathbf{C}_{\mathbf{3}}$ & $\mathbf{C}_{\mathbf{4}}$ & $\mathbf{C}_{\mathbf{5}}$ & $\mathbf{C}_{\mathbf{6}}$ & $\mathbf{C}_{\mathbf{7}}$ & $\mathbf{C}_{\mathbf{8}}$ & $\mathbf{C}_{\mathbf{9}}$ \\
\hline & $\mathrm{C}_{1}$ & 1 & 1 & 1 & 0.33 & 5 & 1 & 0.33 & 0.33 & 0.25 \\
\cline { 2 - 13 } & $\mathrm{C}_{2}$ & 1 & 1 & 1 & 0.33 & 5 & 1 & 0.33 & 0.33 & 0.25 \\
\cline { 2 - 12 } $\begin{array}{l}\text { Weight } \\
\text { Matrix }\end{array}$ & $\mathrm{C}_{3}$ & 1 & 1 & 1 & 0.33 & 5 & 1 & 0.33 & 0.33 & 0.25 \\
\cline { 2 - 12 } & $\mathrm{C}_{4}$ & 3 & 3 & 3 & 1 & 3 & 1 & 0.33 & 0.33 & 0.33 \\
\cline { 2 - 11 } & $\mathrm{C}_{5}$ & 0.20 & 0.2 & 0.2 & 0.33 & 1 & 0.2 & 0.2 & 0.2 & 0.14 \\
\hline
\end{tabular}




\begin{tabular}{|c|c|c|c|c|c|c|c|c|c|c|}
\hline & $\mathrm{C}_{7}$ & 3 & 3 & 3 & 3 & 5 & 3 & 1 & 1 & 1 \\
\hline & $\mathrm{C}_{8}$ & 3 & 3 & 3 & 3 & 5 & 3 & 1 & 1 & 1 \\
\hline & $\mathrm{C}_{9}$ & 4 & 4 & 4 & 3 & 7 & 3 & 1 & 1 & 1 \\
\hline \multirow{9}{*}{$\begin{array}{c}\text { Normalized } \\
\text { Weight } \\
\text { Matrix }\end{array}$} & $\mathrm{C}_{1}$ & 0.06 & 0.06 & 0.06 & 0.03 & 0.12 & 0.07 & 0.07 & 0.07 & 0.05 \\
\hline & $\mathrm{C}_{2}$ & 0.06 & 0.06 & 0.06 & 0.03 & 0.12 & 0.07 & 0.07 & 0.07 & 0.05 \\
\hline & $\mathrm{C}_{3}$ & 0.06 & 0.06 & 0.06 & 0.03 & 0.12 & 0.07 & 0.07 & 0.07 & 0.05 \\
\hline & $\mathrm{C}_{4}$ & 0.17 & 0.17 & 0.17 & 0.08 & 0.07 & 0.07 & 0.07 & 0.07 & 0.07 \\
\hline & $\mathrm{C}_{5}$ & 0.01 & 0.01 & 0.01 & 0.03 & 0.02 & 0.01 & 0.04 & 0.04 & 0.03 \\
\hline & $\mathrm{C}_{6}$ & 0.06 & 0.06 & 0.06 & 0.08 & 0.12 & 0.07 & 0.07 & 0.07 & 0.07 \\
\hline & $\mathrm{C}_{7}$ & 0.17 & 0.17 & 0.17 & 0.24 & 0.12 & 0.21 & 0.20 & 0.20 & 0.22 \\
\hline & $\mathrm{C}_{8}$ & 0.17 & 0.17 & 0.17 & 0.24 & 0.12 & 0.21 & 0.20 & 0.20 & 0.22 \\
\hline & $\mathrm{C}_{9}$ & 0.23 & 0.23 & 0.23 & 0.24 & 0.17 & 0.21 & 0.20 & 0.20 & 0.22 \\
\hline
\end{tabular}

Source: Done by the authors.

Table 4 illustrates the results found after applying the traditional AHP method.

Table 4. Results (traditional AHP)

\begin{tabular}{ccc}
\hline Classification & Alternative & Score \\
\hline $1^{\text {st }}$ option & $(3)$ totally new model & 0.3949 \\
\hline $2^{\text {nd }}$ option & $(2)$ & 0.3207 \\
\hline $3^{\text {rd }}$ option & (1) current model & 0.2843 \\
\hline
\end{tabular}

Source: Done by the authors.

Analyzing the results shown in Table 4, after applying the traditional AHP method, we can see that the best construction alternative, even considering the risks involved, is model (3). Meanwhile, the worst alternative is replicating the current model (1). The traditional AHP method generated a small discrimination among alternatives, which may indicate the need for a more careful sensitivity analysis. To increase the discriminatory power, we propose the following: to calculate the standard deviation of the alternatives for each criterion, to calculate de Gaussian factor for each criterion, to calculate the Pearson's correlation module among the criteria in order to have a greater discrimination of the criteria weights and compensate the weights generated by the AHP-Gaussian through the values generated by the Pearson correlation. The new results can be found in Table 5.

Table 5. Results (New approach to the AHP - Gaussian Factor + Pearson's Correlation)

Source: Done by the authors.

\begin{tabular}{ccc}
\hline Classification & Alternative & Score \\
\hline $1^{\text {st }}$ option & $(3)$ totally new model & 0.5193 \\
\hline $2^{\text {nd }}$ option & $(2)$ & 0.2750 \\
\hline $3^{\text {rd }}$ option & (1) current model & 0.2057 \\
\hline
\end{tabular}

It is possible to notice that we obtained the same ranking in both methods. By using the Gaussian factor and the Person's correlation to greater differentiate the criteria weights, we were able to further legitimize that model 3 is the best option to be built.

\section{Conclusion}

For over one hundred and thirty years, Brazil has lived at peace with its neighbors, however, this does not mean the end of external threats. History clearly demonstrates the need for a nation to have naval power that inspires credibility. In general, in most 
countries it is up to the naval power to guarantee the integrity of the territory, national sovereignty and defend the interests of the nation in its waters, aiming to ensure the right to the strategic and economic use of the sea and inland waters. Due to the phenomenon of globalization, the struggle to defend national interests, whether political, economic or strategic military, paradoxically, has been much more forceful than in past decades. Opposing globalization is not productive, as it tends to expand more and more, with implications for the performance of the armed forces. There is a time when many solutions from the past no longer apply. There is a need to evolve in organizational terms and management methods.

Thus, this article proposes a new approach to the AHP method by combining the Gaussian factor and the Pearson's correlation in order to have a greater differentiation among the alternatives. Through interviews carried out with specialists from the BN, we elicited the weights and ranked the potential warships to be built by the BN. The conclusion was that, for the Brazilian scenario, the best solution is to build a completely new ship, which was later corroborated through a sensitivity analysis. For future studies, the methodology used in this article can be adapted to other contexts: in other industries, in other countries, with different databases. It is also interesting to apply different methods to prove the robustness of the results found, as we did in this article. The results found in this paper were forwarded to the Brazilian navy.

\section{References}

[1] Ministério da Defesa do Brasil. Estratégia Nacional de Defesa. Brasília: Ministério da Defesa do Brasil, 2016. 11 pages. Available in: https://www.gov.br/defesa/pt-br/arquivos/estado_e_defesa/pnd-end2016.pdf. Accessed in: 08 fev. 2021.

[2] ALMEIDA, Isaque David Pereira de; CORRIÇA, José Victor de Pina; COSTA, Arthur Pinheiro de Araújo; COSTA, Igor Pinheiro de Araújo; MAêDA, Sérgio Mitihiro do Nascimento; GOMES, Carlos Francisco Simões; SANTOS, Marcos dos. Study of the Location of a Second Fleet for the Brazilian Navy: structuring and mathematical modeling using sapevo-m and vikor methods. Production Research, [S.L.], p. 113-124, 2021. Springer International Publishing. http://dx.doi.org/10.1007/978-3-030-76310-7 9.

[3] MOREIRA, Miguel Ângelo Lellis; COSTA, Igor Pinheiro de Araújo; PEREIRA, Maria Teresa; SANTOS, Marcos dos; GOMES, Carlos Francisco Simões; MURADAS, Fernando Martins. PROMETHEE-SAPEVO-M1 a Hybrid Approach Based on Ordinal and Cardinal Inputs: multi-criteria evaluation of helicopters to support brazilian navy operations. Algorithms, [S.L.], v. 14, n. 5, p. 140, 27 abr. 2021. MDPI AG. http://dx.doi.org/10.3390/a14050140

[4] TENÓRIO, Fabricio Maione; SANTOS, Marcos dos; GOMES, Carlos Francisco Simões; ARAUJO, Jean de Carvalho. Navy Warship Selection and Multicriteria Analysis: the thor method supporting decision making. Industrial Engineering And Operations Management, [S.L.], p. 27-39, 2020. Springer International Publishing. http://dx.doi.org/10.1007/978-3-030-56920-4_3

[5] GOMES, Carlos Francisco Simões; SANTOS, Marcos dos; TEIXEIRA, Luiz Frederico Horácio de Souza de Barros; SANSEVERINO, Adriana Manzolillo; BARCELOS, Mara Regina dos Santos. SAPEVO-M: a group multicriteria ordinal ranking method. Pesquisa Operacional, [S.L.], v. 40, p. 1-23, 2020. FapUNIFESP (SciELO). http://dx.doi.org/10.1590/0101-7438.2020.040.00226524

[6] OLIVEIRA, Altina S.; GOMES, Carlos F. S.; CLARKSON, Camilla T.; SANSEVERINO, Adriana M.; BARCELOS, Mara R. S.; COSTA, Igor P. A.; SANTOS, Marcos. Multiple Criteria Decision Making and Prospective Scenarios Model for Selection of Companies to Be Incubated. Algorithms, [S.L.], v. 14, n. 4, p. 111, 30 mar. 2021. MDPI AG. http://dx.doi.org/10.3390/a14040111

[7] RODRIGUES, Marcus Vinícius Gonçalves; DUARTE, Thamires Eis; SANTOS, Marcos dos; GOMES, Carlos Francisco Simões. Prospective scenarios analysis: impact on demand for oil and its derivatives after the covid-19 pandemic. Brazilian Journal Of Operations \& Production Management, [S.L.], v. 18, n. 2, p. 1-15, jun. 2021. Associacao Brasileira de Engenharia de Producao - ABEPRO. http://dx.doi.org/10.14488/bjopm.2021.039. Available in: https://bjopm.emnuvens.com.br/bjopm/ article/view/1215/998. Accessed on 03 apr. 2021. 
[8] COSTA, Igor Pinheiro de Araújo; MAêDA, Sérgio Mitihiro do Nascimento; TEIXEIRA, Luiz Frederico Horácio de Souza de Barros; GOMES, Carlos Francisco Simões; SANTOS, Marcos dos. Choosing a hospital assistance ship to fight the covid-19 pandemic. Revista de Saúde Pública, [S.L.], v. 54, p. 79, 10 ago. 2020. Universidade de Sao Paulo, Agencia USP de Gestao da Informacao Academica (AGUIA). http://dx.doi.org/10.11606/s1518-8787.2020054002792

[9] JARDIM, R. R. J.; SANTOS, M.; E. NETO,; SILVA, E. da; BARROS, F. de. Integration of the waterfall model with ISO/IEC/IEEE 29148: 2018 for the development of military defense system. Ieee Latin America Transactions, [S.L.], v. 18, n. 12, p. 2096-2103, dez. 2020. Institute of Electrical and Electronics Engineers (IEEE). http://dx.doi.org/10.1109/tla.2020.9400437

[10] MOREIRA, Miguel Ângelo Lellis; GOMES, Carlos Francisco Simões; SANTOS, Marcos dos; SILVA, Marcela do Carmo; ARAUJO, Jonathas Vinícius Gonzaga Alves. PROMETHEE-SAPEVO-M1 a Hybrid Modeling Proposal: multicriteria evaluation of drones for use in naval warfare. Industrial Engineering And Operations Management, [S.L.], p. 381-393, 2020. Springer International Publishing. http://dx.doi.org/10.1007/978-3-030-56920-4 31.

[11] Saaty, T. L. (1980) Analytic Hierarchy Process. New York: McGraw Hill.

[12] SANTOS, M.; COSTA, I. P. ARAUJO; GOMES, C. F. S (2021). Multicriteria Decision-Making In The Selection Of Warships: A New Approach To The AHP Method. International Journal of the Analytic Hierarchy Process, v. 13, p. 1-13.

[13] DE SOUZA, L. P.; GOMES, C. F. S.; DE BARROS, A. P. (2018). Implementation of new Hybrid AHPTOPSIS-2N method in sorting and prioritizing of an it capex project portfolio. International journal of information technology \& decision making, v. 17, p. 977-1005.

[14] Vogt, R. (2013). Corvetas Sucessoras da Barroso: comparação de dois tipos de obtenção. Revista Marítima Brasileira, Rio de Janeiro, 133(04/06), 108-129. 